\title{
Footings of Residential Buildings, Erected on Clay Soils with Organic Content
}

\author{
Dmitry Chunyuk ${ }^{1}$, and Olga Kopteva ${ }^{1, *}$ \\ ${ }^{1}$ Moscow State University of Civil Engineering, Yaroslavskoe shosse, 26, Moscow, 129337, Russia
}

\begin{abstract}
In the proposed article the author examines issues determining physical and mechanical soils with organic matter content. Conditional definitions of organic soils depending on the value of the relative organic content matter are determined. The biogenic soils are examined using three groups - peat, blocked soils and sapropels. Depending on the relative content of organic substances, the author compares various peat types. The division of the soils with organic content is presented. A definition of sapropels is presented. The problem of complexity of determination of the amount of organic substances by calcination of samples is described. The current methods used to determine the amount of organic substances currently in Russia isexamined. The paper reviews physical and mechanical properties of organic soils. The on-site test-plate data is compared with laboratory test data. The problems of sapropel tests are described. The results of experimental studies, conducted at a construction site in the new suburban district of Moscow are shown.
\end{abstract}

\section{Introduction}

Swamp and boggy lands occupy large areas worldwide. Such areas in Canada occupy 170 $\mathrm{mln}$ ha, and $150 \mathrm{mln}$ ha in Russia. This situation is an issue for railroads and highways, passing through boggy lands, and large construction sites, consisting of soils rich in organic matter.

The last 70 years in Russia saw investigations of such soil properties as well as measurement of the properties of clay soils, containing organic inclusions, in relation to the applied methods and subsoil-footing interaction analyses.

Organic matter content analysis is mandatory for sand and sand-silt tests in Russia. Relative organic matter content is evaluated as organic matter content in the

the total sample mass ratio.

By the relative organic matter content the soils are defined as "soils with organic matter admixture" if the organic matter content varies between $0,03-0,1$. Such soils in Russia in geotechnical survey belong to the group of biogenic soils, classified as peats, peaty soils and sapropels.

\footnotetext{
* Corresponding author: mocka@list.ru
} 
Soil, containing 50\% and more of organic matter are classified as peats. It is assumed that organic matter resulted from swamp plants decomposition in high moisture content environment and the shortage of oxygen.

Depending on the relative organic matter content the peat varieties are classified as lowdegraded, if their organic matter degradation is below $20 \%$, medium degraded with degradation rate of $20-45 \%$ and highly degraded with the degradation rate over $45 \%$.

Peat-containing soils include sandy and silty clay soils, containing $10-50 \%$ mass of organic content. The peaty soils are classified as low peat content (relative organic content is 0.1-0.25), medium content (relative organic content rate is 0.25-0.40) and high peat content (with relative organic matter content over).

Sapropels include the fresh-water silt, formed up due to degradation of organic plant residues at the bottom of stagnant water bodies. Usually sapropels contain over $10 \%$ of organic matter. The sapropel structure changes by compaction, porosity decreases, and such soils are called saprocols. Sapropels are classified by their organic matter content as mineral ones $(0,10-0,30)$; medium mineral content $(0,30-0,50)$ and low mineral content (more than 0,50 ) ones.

\section{Methods}

Determination of organic matter content is an important issue. It often happens that the organic matter content was determined by ignition of the samples at $600-900{ }^{\circ} \mathrm{C}$. The loss of mass due to ignition indicated the organic content. But the new research showed that both organic. fine clay and silt particles as well as salts burn out. Therefore, in Russia the organic matter content is currently measured by carbon content (method of I.V.Tyurin, modified by Simakov).

Due to the fact that thick sapropel strata (saprocols) are seldom used as subsoil for residential buildings higher than 35 stories (high-rise building construction) a necessity emerged to re-investigate specific physical and mechanical properties of such soils. Therefore, the authors collected and analyzed archive and published material from various geological organizations (deformation and strength parameters of sapropels).

Conventionally, all sapropels are classified as lacustrine, swamp and lacustrine-swamp ones mainly buried under the layer of other soils.

Sapropel mineral part analysis showed that they can mainly be calcareous (containing $\mathrm{CaCO} 3$ carbonate and silicon containing ones). The sapropel water content varies from 120 to $600 \%$. Sapropel particles density lowers versus moisture content growth from 2,3 to 1,8 $\mathrm{g} / \mathrm{cm} 3$. The sapropel porosity ratios vary within $1,4-9,6$ range.

The analysis of the investigations, carried out in 1950-1990s in Belorussia as well as in north-east areas of Russia demonstrated that such sapropel deformation modulus was assumed as 2-14 $\mathrm{MPa}$ and up to $0,05-0,1 \mathrm{MPa}$ due to change of vertical pressures on samples. All researches established that the more mineral particles are present in the sapropels the greater is the sapropel strength.

The experiment investigations were carried out in the new neighborhood of Moscow i.e., Luberetsky aeration sites. We performed these investigations for the project engineers and the customer.

As per survey data on sites of neighborhoods \#13 and 17 the buildings' subsoils contain thick sapropel strata which ought to be better called saprocols.

The site survey included both laboratory and field tests. According to survey data from drilled holes up to $42 \mathrm{~m}$ deep, CPT, in situ plate tests, laboratory tests, the 17 to 25 storey high-rise site subsoil features the following soil strata. 
Contemporary swamp deposits occur below a medium thickness stratum, represented by two layers of different color: black to light-brown, having different consistency of soft plastic to hard, 4.6-8.1 m thick. Organic content in various samples amounts to $10-21 \%$.

Sapropels, with color varying from black and dark-grey to light-brown, are 6.0-9.6 m thick.

These layers are underlain by alluvial sands, saturated, dense, containing carbonate coarse grain debris.

Below are limestones, defined as Upper Carbon.

This site was investigated by CPT Fugro and Pika-17 continuous down-pushing to determine the soil strata homogeneity in general. The CPT tests measured qc and fs. CPTs were performed near test holes, drilled earlier, in order to specify the probe resistance.

At the site soil properties were also investigated by test plate loading. The tests in the holes were performed with Kashirsky $600 \mathrm{~cm} 2$ area plate.

The undisturbed soil samples (monoliths) taken from the test hole (undisturbed) were at least $108 \mathrm{~mm}$ dia and at least $20 \mathrm{~mm}$ high. These samples were brought to the laboratory, where soil design parameters were investigated, required for the structures' subsoil strength and stability analyses. E.g., stiff clay with 5.3-7.9 organic content had filtration consolidation ratio $\mathrm{CHv}=0,008 \mathrm{~cm} 2 / \mathrm{min}$ while its undrained shear resistance was $\mathrm{CHu}=29$ $\mathrm{kPa}$.

Hard clays with organic matter content up to $40 \%$ consolidations ratio $40 \%$ had filtration consolidation ratio $\mathrm{CHv}=0.018 \mathrm{~cm} 2 / \mathrm{min}$ while the undrained shear resistance $\mathrm{CHu}=18 \mathrm{kPa}$.

Clay soils, having low organic content, related to the sapropel (saprocol) stratum, were investigated in most detail. The filtration consolidation ratio of this soil was $\mathrm{CHv}$ $=0,0011 \mathrm{~cm} 2 / \mathrm{mi}$ while its undrained shear resistance was $\mathrm{CHu}=7,8 \mathrm{kPa}$.

The sapropel, compacted to porosity ratio 1.3 and less, are called sapprocols.

Determination of sapropel design parameters for the project engineers to analyze footing bearing capacity and settlement is a complicated problem.

The data analysis from the tests, performed to investigate sapropel propertis in Belorussia, in Leningrad and in Moscow region, demonstrated that the sapropel deformation parameters, measured in laboratory compression tests, was essentially (times 6-18) different from the $500 \mathrm{~cm} 2$ and $3000 \mathrm{~cm} 2$ plate test data.

Therefore, in order to carry out experiments on "Nekrasovka" site in Moscow, 3 test sites were set up at the construction site of block 5 in neighborhood 13 (A, B) and at the block 6B site in the same neighborhood.

Test pits were excavated on the test sites, penetrating the peat-containing soil strate down to the boundary of the sapropel stratum. Soil samples were taken from the sapropel stratum by the method of cutting ring. The samples were preserved (in wax or latex) and delivered to the laboratory where soil strength parameters

$(\varphi, c)$, compressibility $(E)$ and permeability ratio in vertical and horizontal directions were measured.

From these samples cut from sapropel strata smaller samples we cut out for triaxial testing.

\section{Results}

Some results are given below. 


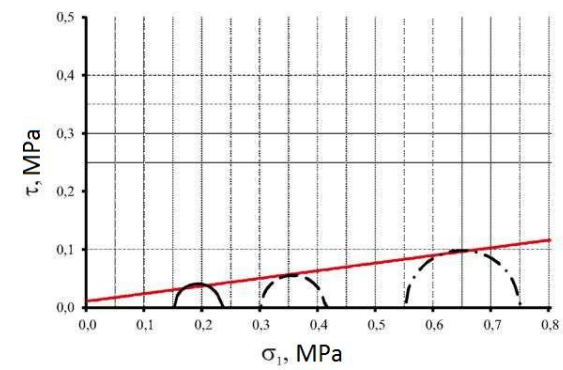

Fig. 1. Coulomb-Mohr diagram. Test pit 13163-15, sampling depth $15.5 \mathrm{~m}$

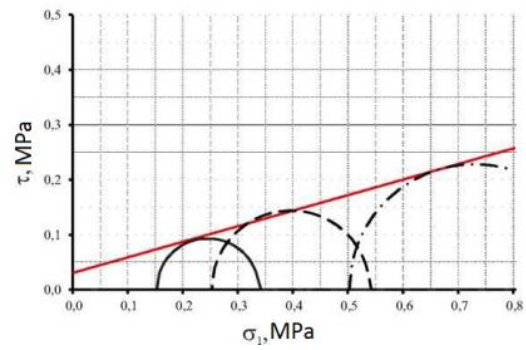

Fig. 2. Coulomb-Mohr diagram. Test pit 13163-15, sampling depth $10.8 \mathrm{~m}$

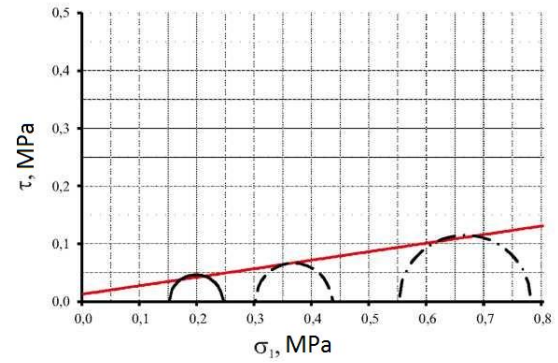

Fig. 3. Coulomb-Mohr diagram. Sampling pit 13166-15, sampling depth $14.0 \mathrm{~m}$

Soil deformation parameters in situ were tested by $600 \mathrm{~cm}^{2}$ plate. In five test pits $325 \mathrm{~mm}$ dia screw tests were conducted. Some results are given on pictures and in tables below.

Table 1. Geological lithological section. Borehole 13160-15.

\begin{tabular}{|c|c|c|c|c|c|c|}
\hline \multirow{2}{*}{$\begin{array}{c}\text { Geological } \\
\text { column and } \\
\text { test plate } \\
\text { location }\end{array}$} & \multirow{2}{*}{$\begin{array}{l}\text { No. } \\
\text { EGE }\end{array}$} & \multirow{2}{*}{$\begin{array}{l}\text { Footing } \\
\text { depth, m }\end{array}$} & \multirow{2}{*}{$\begin{array}{c}\text { Strata } \\
\text { thickness }\end{array}$} & \multicolumn{2}{|c|}{ Ground waters } & \multirow{2}{*}{ Strata description } \\
\hline & & & & New & Standing & \\
\hline & 200 & 1,70 & 1,70 & & & $\begin{array}{l}\text { Technogenic sand, } \\
\text { medium grain size, with } \\
\text { fine inclusions, } \\
\text { yellowish, brown, loose, } \\
\text { low water saturation } \\
\text { rate, tQIV }\end{array}$ \\
\hline 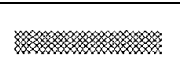 & 200 & 2,70 & 1,00 & & & $\begin{array}{l}\text { Technogenic sand, } \\
\text { medium grain size, with }\end{array}$ \\
\hline
\end{tabular}




\begin{tabular}{|c|c|c|c|c|c|c|}
\hline & & & & & & $\begin{array}{l}\text { fine inclusions, } \\
\text { yellowish-brown, } \\
\text { medium density, low } \\
\text { water saturation rate, } \\
\text { tQIV }\end{array}$ \\
\hline & 200 & 5,30 & 2,60 & & & $\begin{array}{lc}\text { Technogenic } & \text { sand, } \\
\text { medium grain size, } \\
\text { yellowish-brown, } \\
\text { medium density, low } \\
\text { water saturation rate, } \\
\text { tQIV }\end{array}$ \\
\hline 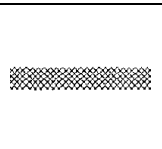 & 200 & 6,30 & 1,00 & & & $\begin{array}{l}\text { Technogenic sand, } \\
\text { medium size with fine } \\
\text { inclusions, low water } \\
\text { saturation rate, tQIV }\end{array}$ \\
\hline 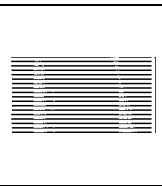 & $12 \mathrm{a}$ & 10,70 & 4,40 & 10,40 & 6,30 & $\begin{array}{l}\text { Clay black, gray-black, } \\
\text { tough, water saturated } \\
\text { sand interlayers, low } \\
\text { organic content, low peat } \\
\text { rate, bQIII-IV }\end{array}$ \\
\hline 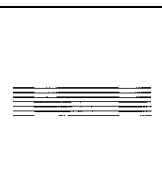 & $12 \mathrm{~b}$ & 12,30 & 1,60 & & & $\begin{array}{l}\text { Clay black, stiff, with } \\
\text { water saturated soil } \\
\text { inclusions, low organic } \\
\text { content, low peat } \\
\text { content, bQIII-IV }\end{array}$ \\
\hline 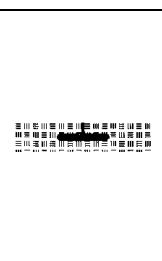 & $13 \mathrm{a}$ & 17,70 & 5,40 & & & $\begin{array}{l}\text { Sapropel (clay), black, } \\
\text { dark grey, stiff, soft } \\
\text { inclusions, } \\
\text { inclusion, low organic } \\
\text { content, medium peat } \\
\text { content, mineral, bQIII- } \\
\text { IV }\end{array}$ \\
\hline
\end{tabular}

Table 2. Soil physico-mechanical properties. Borehole 13160-15, test plate depth 13,00 m.

\begin{tabular}{|c|c|c|c|c|c|c|c|c|c|c|c|}
\hline \multirow[b]{2}{*}{$\begin{array}{c}\text { Soil } \\
\text { name }\end{array}$} & \multirow[b]{2}{*}{$\underset{\#}{\text { Borehole }}$} & \multirow[b]{2}{*}{$\begin{array}{l}\text { Sampling } \\
\text { depth, m }\end{array}$} & \multirow[b]{2}{*}{$\begin{array}{l}\text { Particle } \\
\text { density } \\
\text { g/cm }\end{array}$} & \multirow[b]{2}{*}{$\begin{array}{c}\text { Soil } \\
\text { density } \\
\text { g/cm }\end{array}$} & \multirow[b]{2}{*}{$\begin{array}{l}\text { Void } \\
\text { ratio }\end{array}$} & \multirow[b]{2}{*}{$\begin{array}{c}\text { Natural } \\
\text { water } \\
\text { content }\end{array}$} & \multirow[b]{2}{*}{$\begin{array}{c}\text { Water } \\
\text { saturation } \\
\text { ratio }\end{array}$} & \multicolumn{2}{|c|}{$\begin{array}{l}\text { Water } \\
\text { content }\end{array}$} & \multirow[b]{2}{*}{$\begin{array}{c}\text { Plasticity } \\
\text { index }\end{array}$} & \multirow[b]{2}{*}{$\begin{array}{c}\text { Liquidity } \\
\text { index }\end{array}$} \\
\hline & & & & & & & & $\begin{array}{c}\text { Plastic } \\
\text { limit }\end{array}$ & $\begin{array}{l}\text { Liquid } \\
\text { limit }\end{array}$ & & \\
\hline $\begin{array}{l}\text { Sapropel } \\
\text { High } \\
\text { mineral } \\
\text { content }\end{array}$ & $\begin{array}{l}1316 \\
0-15\end{array}$ & 14,50 & 2,43 & 1,25 & 4,09 & 161,6 & 1,0 & 111,4 & 196,5 & 85,10 & 0,59 \\
\hline
\end{tabular}

Table 3. Geological lithological section. Borehole 13163-15.

\begin{tabular}{|c|c|c|c|c|c|}
\hline \multirow{2}{*}{$\begin{array}{l}\text { Geological column } \\
\text { and test plate } \\
\text { location }\end{array}$} & \multirow{2}{*}{$\begin{array}{l}\text { No. } \\
\text { EGE }\end{array}$} & \multirow{2}{*}{$\begin{array}{l}\text { Footing } \\
\text { depth, } \\
\text { m }\end{array}$} & \multirow{2}{*}{$\begin{array}{c}\text { Strata } \\
\text { thickness }\end{array}$} & $\begin{array}{c}\text { Ground } \\
\text { waters }\end{array}$ & \multirow{2}{*}{ Strata description } \\
\hline & & & & stable & \\
\hline
\end{tabular}




\begin{tabular}{|c|c|c|c|c|c|c|}
\hline & 200 & 4,70 & 4,70 & & & $\begin{array}{l}\text { Technogenic soil, } \\
\text { medium grain, fine } \\
\text { inclustions, yellowish- } \\
\text { brown, loose, low water } \\
\text { saturation rate, tQIV }\end{array}$ \\
\hline & 200 & 6,90 & 2,20 & & & $\begin{array}{l}\text { Technogenic soil, } \\
\text { medium grain sand, } \\
\text { fine inclusions, } \\
\text { yellowish-brown, low } \\
\text { saturation rate, tQIV }\end{array}$ \\
\hline$\overline{\equiv \bar{\equiv}}$ & $12 \mathrm{a}$ & 8,10 & 1,20 & & & $\begin{array}{l}\text { Clay black, stiff, with } \\
\text { water-saturated sand } \\
\text { inclusions, low organic } \\
\text { content, low peat rate, } \\
\text { bQIII-IV }\end{array}$ \\
\hline 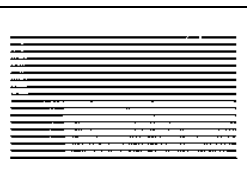 & $12 b$ & 12,70 & 4,60 & & & $\begin{array}{l}\text { Clay black, stiff, with } \\
\text { water-saturated sand } \\
\text { inclusions, low organic } \\
\text { content, low peat rate, } \\
\text { bQIII-IV bQIII-IV }\end{array}$ \\
\hline 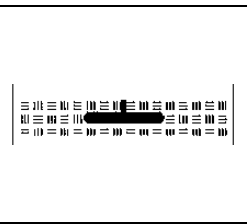 & $13 a$ & 18,90 & 6,20 & 9,70 & 5,00 & $\begin{array}{l}\text { Sapropel (clay) black, } \\
\text { stratified, stiff, soft } \\
\text { inclusions, low organic } \\
\text { rate, medium peat rate, } \\
\text { black, dark grey, } \\
\text { mineral, bQIII-IV }\end{array}$ \\
\hline
\end{tabular}

Table 4. Soil physico-mechanical properties. Borehole 13163-15, test plate depth $13.00 \mathrm{~m}$.

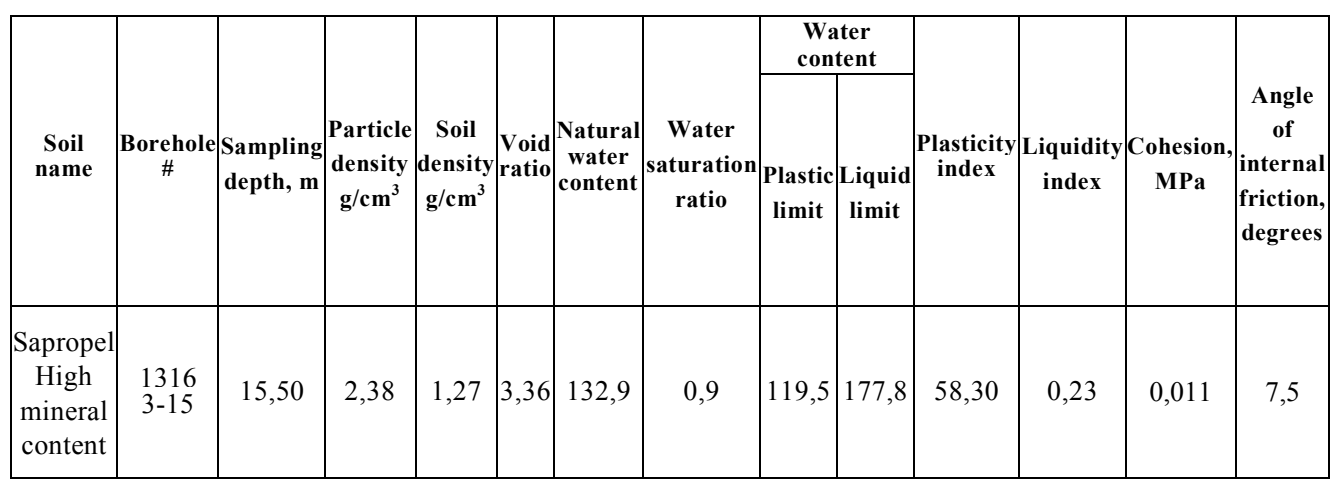

Because there exists a viewpoint that soil deformation parameters, determined by 600 $\mathrm{cm}^{2}$ test plate are essentially different form similar parameters, obtained by $3000 \mathrm{~cm}^{2}$ and $5000 \mathrm{~cm}^{2}$ plate tests, we also tested deformability of sapropel soils with $3000 \mathrm{~cm}^{2}$ plates (on test site \#2).

In situ soil plate tests photos are shown below: 


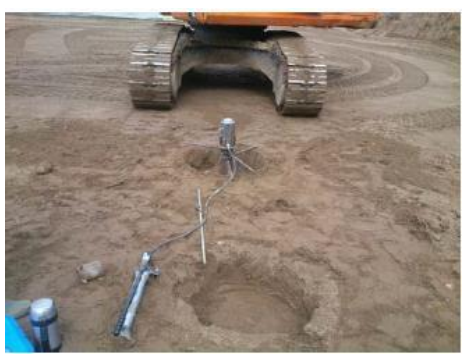

Fig. 4. Operation surface preparation prior to test

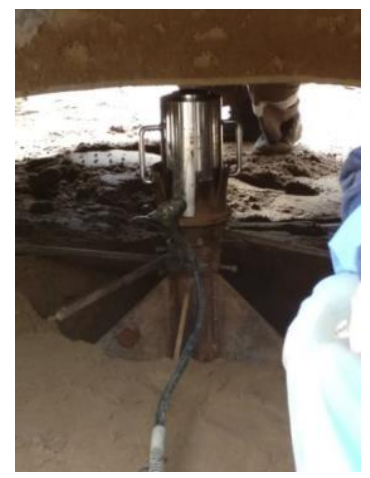

Fig. $5.3000 \mathrm{~cm} 2$ test plate, supported by an excavator shovel bucket to ensure the specified pressure under the plate

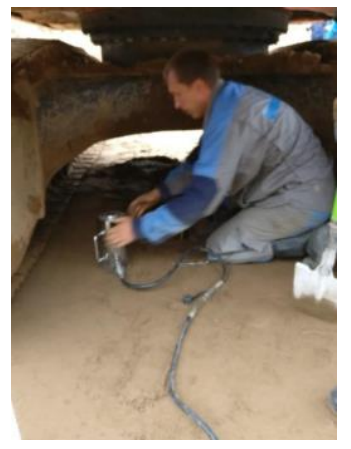

Fig. 6. Plate test operation on line

\section{Discussion}

Analysis of laboratory and in-situ test data on sapropel deformability enabled the following conclusions:

1. The deformation modulus of the tested sapropels, determined by data from laboratory tests, are times 8-17 less than the value of the plate test modulus;

2. It was established that in the course of sapropel compression test, stabilization of test plate settlements both in the hole and in the subsoil under large diameter $(3000 \mathrm{~cm} 2)$ plates is much greater than in ordinary clay soils of plastic consistency. This fact ought to be taken into account during plate tests on sapropels.

3. Comparison of $600 \mathrm{~cm} 2$ plate test data with that of $3000 \mathrm{~cm} 2$ plate test data demonstrated that the value of the respective deformation modulus under test plates of greater diameter is times 2,3 - 4,3 greater than that of $600 \mathrm{~cm} 2$ one. The up-to-date 
computer analysis, applied to determine a building virtual stability, possible tilt in the course of operation, installation of deep footings and different piles as well as for the design of a "bore wall" it is necessary to know the values of soil strength parameters.

Sapropel strength parameters were conducted in laboratory in direct shear devices on 60 $\mathrm{cm} 2$ area samples (Gidroproject design) and in triaxial apparatus on $3.6 \mathrm{~cm}$ dia samples.

Direct shear tests were done according to the conventional method, however, there occurred uncertainty in registrating the sample shear moment. Usually mineral samples are sheared or split at $3 \mathrm{~mm}$ slider movement. This is the criterion for identifying soil strength parameters. Unfortunately, there was no shear failure in sapropel samples taken from test site \#1 (Building \#5, Aprt. 13(A, B) in Nekrasovka, Moscow) neither at $3 \mathrm{~mm}, 5 \mathrm{~mm}$ or more just the sample front portion crushed.

Similar problems emerged during the tests sapropel samples, taken for the same pits. The sample in a triaxial apparatus deformed, following the load growth, no "split", however, occurred.

Similarly, to the test techniques for soft saturated clay soils it is necessary to indicate what strength parameters correspond to vertical deformations. E.g. if vertical deformation is $5 \%$ then $\varphi=20^{\circ}$ and $\mathrm{c}=0.01 \mathrm{MPa}$.

For sample vertical deformation $10 \% \varphi=17^{\circ}$, and $\mathrm{c}=0.03 \mathrm{MPa}$.

For vertical deformation $12 \%, \varphi$ was $16^{\circ}$, and $\mathrm{c}=0.06 \mathrm{MPa}$.

There was an attempt to determine the sample stress and strain state in a triaxial apparatus by measuring pore pressure in the lower plate.

Unfortunately, in the cases of partly saturated soil this method failed. However, when the clay sample was water saturated (humidity rate over 0.93 ) the sample collapse moment was registered as sharp pore pressure rise.

There are currently several schemes in Russia for determining soil strength parameters. These are consolidated drained test, non-consolidated and non-drained test, etc.

According to investigation, conducted on 16 sapropel samples, tested in triaxial and direct shear "Gidroproekt" devices the closest test results were obtained after investigation of sapropel strength parameters in triaxial compression devices with measured pore pressure and results of one-plane shear devices by fast shear method (Maslov).

For projects on sapropels it is necessary to consider that chemically they contain pore water, aggressive to steel and concrete.

Therefore, it is recommended to use either hydro-isolated piles or those made of special concrete.

A large raft footing is the most applied design solution for civil structures, sitting on a 1.5-3.0 $\mathrm{m}$ thick sand layer. The layer shall be filled with maximally compacted coarse or medium coarse sand.

This work was financially supported by Ministry of Education and Science of the Russian Federation (\#NSh-3492.2018.8).

\section{References}

1. State standard 25100-2011. Soils. Classification. Interstate council for standardization, metrology and certification (2013)

2. V.A.Ilichev, R.A. Mangushev and others, Reference book of geotechnics. Foundations, foundations and underground structures (Publishing house ASV, 2016)

3. Engineering survey for construction. Basic principles - 47.13330.2012 (2013)

4. P.A. Konovalov, Foundation of buried ground, Stroyizdat (Stroyizdat, 1980)

5. P. A. Konovalov, Construction of structures by peaty areas (Stroyizdat, 1995) 